\title{
COMPARISON OF THE EFFECTS OF FOETAL BOVINE CALF SERUM WITH THOSE OF BOTH CAMEL AND RABBIT SERUM ON SOME TYPES OF TISSUE CULTURE
}

\author{
MARWA F. MAHMOUD ${ }^{1}$ and NAGLAA I. HASSAN ${ }^{2}$ \\ ${ }^{1}$ Virology Unit, Department of Reproductive Disease. Animal Reproduction Research Institute (ARRI), Agriculture \\ Research Center (ARC), Giza, Egypt. \\ ${ }^{2}$ Mycoplasma Unit, Department of Reproductive Disease. Animal Reproduction Research Institute (ARRI), Agriculture \\ Research Center (ARC), Giza, Egypt.
}

Received: 25 September 2019; Accepted: 21 October 2019

\begin{abstract}
We sought to investigate the feasibility of decreasing FBS or supplanting it with less expensive and more easily accessible sera, such as camel serum (CS) and rabbit serum (RS). Quality tests were performed for all three types of serum (commercial FBS, CS and RS). After MDBK and VERO cell lines were passaged three times for adaptation to CS and RS, the viability and damage levels in the cells cultured using the three types of serum were compared by3-(4,5dimethylthiazolyl-2)-2,5-diphenyltetrazolium bromide (MTT) and comet assays. The results revealed that the best type of serum according to the MTT assays was (FBS), which improved cell viability from, 0.39 in the first passage to 0.69 in second passage, followed by FBS+ (CS), which improved viability from 0.40 in the first passage to 0.60 in the second passage and CS, which improved viability from 0.34 in the first passage to 0.46 in the second passage. The least suitable serum was RS; RS-cultured cells exhibited viabilities of 0.26 in the first passage and 0.34 in the second passage. The comet assays demonstrated similar outcomes; DNA damage was lowest in cells cultured with FBS, which demonstrated $7 \%$ damage in the first passage and $6 \%$ damage in the second passage, followed by cells cultured with CS, which demonstrated $19.33 \%$ damage in the first passage and 13\% damage in the second passage. RS caused high levels of DNA damage compared with the other sera; $23.33 \%$ in the first passage and $16.13 \%$ in the second passage. Taken together, the results indicate that CS is superior to RS and can be used as a substitute for FBS or in an equal mixture with FBS for enhancement cell culture.
\end{abstract}

Key words: Camel serum, comet assay, foetal bovine serum, MTT assay, rabbit serum.

\section{INTRODUCTION}

To keep cells alive for extended periods of time and to evaluate proliferation, migration and differentiation a basal medium must be supplemented with several factors (Van der Valk et al., 2010). Serum, from animals or humans, is the most commonly used supplement for cell maintenance and proliferation. Foetal bovine serum (FBS) is acceptable for most purposes and is the present gold standard. FBS is a complex mixture of many different factors, such as growth factors, proteins, vitamins, trace elements, hormones, etc., that are essential for the growth and maintenance of cells (Barnes and sato, 1980). However, the use of FBS has raised several concerns in recent years. FBS not only is a potential source of contamination by pathogens such as viruses, mycoplasmas, and prions, but also can increase cell immunogenicity as a result of the internalization of animal proteins during in vitro expansion (Spees et al.,

Corresponding author: Dr. Marwa F. Mahmoud

E-mail address: asiamarwa1911@gmail.com

Present address: Virology Unit, Department of Reproductive Disease. Animal Reproduction Research Institute (ARRI), Agriculture Research Center (ARC), Giza, Egypt
2004 and Jin et al., 2015). Other disadvantages include the significant batch-to-batch variation of FBS, and the possibility that the growing demand for FBS may soon exceed supply (Tekkatte et al., 2011 and Karnieli et al., 2017). Possible strategies to reduce the use of FBS in cell and tissue culture were summarized in 2003 (Van der Valk et al., 2004).

To maintain cells and tissues for extended periods of time, the medium should also contain components such as nutrients and $\mathrm{pH}$ - buffering substances. Harry Eagle formulated a medium with these components, known Eagle's minimal essential medium (Eagle's MEM or MEM). MEM also contains amino acids, glucose and vitamins (Eagle, 1955). A similar basal medium, Dulbecco's modified Eagle's medium, (DMEM), is still used to maintain primary cell cultures and cell lines with ten percent FBS as a supplement in the medium (John et al., 2018).

Various serum components have been successfully used as cell culture supplements for growth. For example, goat serum supplemented growth media have been used in vitro for cultivation of malarial parasites (Smita 2004) and have been used in fish cells (Nanda et al., 2009). In 
addition, human platelet lysates have been used as serum substitutes in cell culture media (Rauch et al., 2011 and Charlotte et al., 2018), as have combination of FBS albumin with insulin transferrin sodium selenite and/or epidermal growth factor (Mesalam et al., 2019). Furthermore, fish serum has been produced as a substitute for FBS (Fransiska et al., 2006). So the aim of this study is searching for another cheap and available source rather than FBS for cells culture.

\section{MATERIALS AND METHODS}

*Serum separation: Serum was separated from the clotted blood of three year-old healthy camels and onemonth-old rabbits in sterile containers. The samples were centrifuged at $3000 \mathrm{rpm}$ for $30 \mathrm{~min}$ to obtain clear serum. Haemolysed serum was excluded because haemoglobin is toxic in tissue cultures. The sera were inactivated at $56^{\circ} \mathrm{C}$ for $30 \mathrm{~min}$ and filtered with $0.2 \mu \mathrm{m}$ filters. The sera were stored at $-20^{\circ} \mathrm{C}$ until use.

\section{**Quality control tests:}

1- The pH levels and haemoglobin concentrations of commercial FBS, camel serum (CS) and rabbit serum (RS) were estimated with $\mathrm{pH}$ meter and spectrophotometers.

2- The total protein in FBS, CS and RS was determined with a biuret-based colorimetric end point method (Doumas et al., 1981). Albumin levels were also determined by a colorimetric end point method with modified bromocresol green (BCG) binding assay (Doumas et al., 1971).

3- The sterility of the CS and RS serums was tested by cultivating the sera on blood agar media (Oxoid 1996) for assessment of aerobic bacteria and on cooked meat broth (Oxoid 1996) for assessment of anaerobic bacteria.

The sera were also cultured in heart infusion (HN) medium as described by Freundt (1983) for mycoplasma isolation. Sabouraud's dextrose agar (2\%) was used for subculture of fungi recovered on the enriched medium (Microbeoline 2014).

4- To make sure the sera were free from viruses, CS and RS were injected into Madine- Darby bovine kidney (MDBK) cells. After 48hr's, the cells were tested for the presence of bovine viral diarrhea virus (BVDV), bovine herpes virus (BHV) and parainfluenza virus type 3 (PI3) by direct and indirect fluorescent antibody techniques according to the methods of (Geetha 2017) Anti-bovine IgG (whole molecule)-FITC, supplied by Sigma-Aldrich, was used at a dilution of 1:300.

5- Indirect ELISA with a BVDV antibody_was used to test the sera for BVDV according to the methods of Edwards (1990). Anti-bovine IgG (whole molecule) peroxidase, supplied by Sigma-Aldrich, was used at dilution of $1: 20,000$.
*** MDBK and VERO cell the viability assessment: a) FBS was progressively substituted with CS and RS in MDBK and VERO cell cultures. In the first passage, $25 \%$ of the $10 \%$ FBS was substituted with CS in one group and with RS in the other group. The percentages of CS and RS were increased to $50 \%$ and $75 \%$ of the $10 \%$ FBS in the second and third passages respectively. In the final passage CS and RS were added alone.

b) The effects of FBS, CS and RS were evaluated by 3(4, 5-dimethylthiazoly 1-2) -2,5- diphenyltetrazolium bromide (MTT) assay and comet assay. MTT assays measure cell proliferation rates; only low background absorbance values appear in the absence of cells. The absorbance depends on the reduction of the yellow tetrazolium dye MTT by metabolically active cells, in part through the action of dehydrogenase enzymes. This reduction generates intracellular purple formazan crystals, which can be solubilized by ethanol and quantified by spectrophotometry at a wavelength of 630 nm (Johan et al., 2011).

In the 96 well plates used for the assays, the columns 1 and 12 and rows $\mathrm{A}$ and $\mathrm{H}$ were neglected to prevent evaporation and were filled with only phosphate buffer saline (PBS). The MDBK cells previously adapted to CS were added to rows $F$ and $G$, the row $F$ medium was supplemented with CS while the row $G$ medium was supplemented with an equal mixture of FBS and CS. The MDBK cells adapted to RS were added to rows $\mathrm{C}$ and D; the row $\mathrm{D}$ row medium was supplemented with $\mathrm{RS}$ while the row $\mathrm{C}$ medium was supplemented with an equal mixture of FBS and RS. MDBK cells without serum were added to row $\mathrm{E}$ as negative controls, and MDBK cells supplemented with FBS were added to row B as positive controls. The sera were added at different percentages; $2 \%$ serum was added in the $2^{\text {nd }}$ and $3^{\text {rd }}$ columns, $4 \%$ serum was added in the $4^{\text {th }}$ and $5^{\text {th }}$ columns, $6 \%$ serum was added in the $6^{\text {th }}$ and $7^{\text {th }}$ columns, $8 \%$ serum was added in the $8^{\text {th }}$ and $9^{\text {th }}$ columns and $10 \%$ serum was added in the $10^{\text {th }}$ and $11^{\text {th }}$ columns. The MTT assay was performed after $48 \mathrm{hr}$ of incubation in a $\mathrm{CO}_{2}$ incubator at $37^{\circ} \mathrm{C}$. The second subculture plate was constructed the same way as the first. The described protocol was also used for VERO cells.

Comet assays were used to detect DNA damage in scratched MBDK and VERO cells cultured with FBS, CS and RS from first and second passages plates according to the methods of Singh et al. (1988) and the results were analysed with a comet assay software program.

**** Statistical analysis: All parameters were statistically analysed via IBM SPSS statistics (version 22). One way ANOVA was used to analyse the variances among the different types of serum and among the different concentrations of each serum in two passages of MTT and comet assays. Differences were considered significant when the P- values were less than 0.05 . 


\section{RESULTS}

Physical and chemical analyses of the commercial FBS, $\mathrm{CS}$ and $\mathrm{RS}$ showed $\mathrm{pH}$ values of 7.4, 7.6 and 7.8 and haemoglobin concentrations of 24, 27 and $30 \mathrm{mg} / 100 \mathrm{ml}$ respectively. The total protein levels determined by the biuret-based colorimetric end point method were 4.97 $\mathrm{g} / \mathrm{dl}, 5.56 \mathrm{~g} / \mathrm{dl}$ and $5.75 \mathrm{~g} / \mathrm{dl}$ for FBS, CS and RS, respectively, and the albumin levels determined by the colorimetric end point method were $2.79 \mathrm{~g} / \mathrm{dl}, 3.54 \mathrm{~g} / \mathrm{dl}$ and $3.25 \mathrm{~g} / \mathrm{dl}$ respectively. Serum contaminated with microorganisms containing BVDV antibodies was excluded.

In MTT assays, the absorbance values in the RS and mixed FBS and RS groups were lower than those in the FBS positive control group indicating reductions in the rates of cell proliferation in the RS-supplemented groups. Conversely, the higher absorbance values in CS and mixed FBS and CS groups compared with the FBS group indicated increases in cell proliferation in the CSsupplemented groups, as shown in (Figure 1).

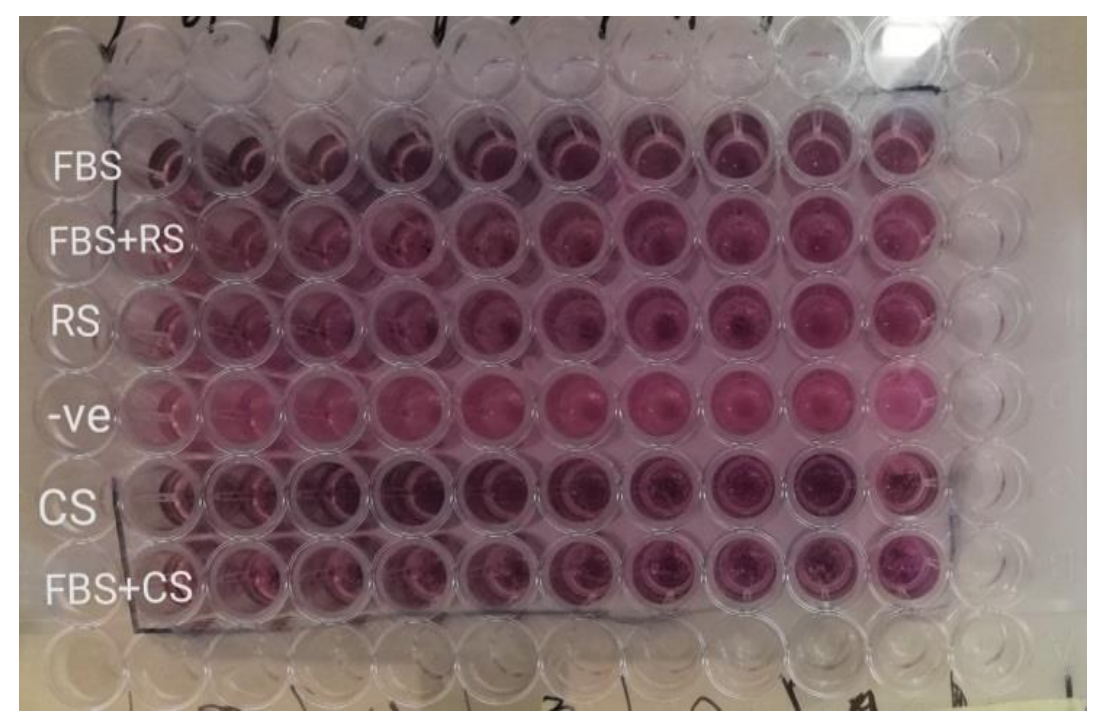

Figure (1): MTT assays were performed in 96 well plates after $48 \mathrm{hr}$ of incubation with 5 types of serum. Row B with FBS, row F with CS and row G with mixed FBS and CS have large amounts of purple formazan crystals, indicating the presence of high numbers of living cells. Row $\mathrm{C}$ with mixed FBS and RS, row D with RS and row E without serum (-ve control) have small amounts of purple formazan crystals as indicating the presence of low numbers of living cells.

The values of cell viability in the second passage were higher than that in the first passage for all types of serum. This increase was due to the adaptation of MDBK and VERO cells to CS and RS. In the first passage, cell viability was the same in the mixed FBS and CS group of MDBK and VERO cells (0.4), as in the FBS group (0.39) while the lowest viability was observed in the RS group,
(0.26). In the second passage the values were increased; FBS was superior to the other sera, contributing to a viability of 0.69 followed by mixed FBS and CS, which contributed to viabilities of 0.6 ; the lowest value, 0.34 , was observed in the RS group these results are shown in (Table 1) and (Figure 2).

Table 1: Effects of different types of serum on cell viability (\%) in first and second passage MTT assays (mean \pm SE).

\begin{tabular}{ccccccc}
\hline & \multicolumn{5}{c}{ Cell viability } & \\
\cline { 2 - 6 } $\begin{array}{c}\text { Passage } \\
\text { number }\end{array}$ & FBS & CS & RS & FBS+CS & FBS+RS & \\
\cline { 2 - 6 } & $0.39 \pm 0.02^{\mathrm{a}}$ & $0.34 \pm 0.04^{\mathrm{ab}}$ & $0.26 \pm 0.03^{\mathrm{b}}$ & $0.40 \pm 0.03^{\mathrm{a}}$ & $0.28 \pm 0.02^{\mathrm{b}}$ & $<0.01$ \\
\hline $1^{\text {st }}$ passage & $0.69 \pm 0.02^{\mathrm{a}}$ & $0.46 \pm 0.03^{\mathrm{b}}$ & $0.34 \pm 0.01^{\mathrm{c}}$ & $0.60 \pm 0.04^{\mathrm{a}}$ & $0.39 \pm 0.02^{\mathrm{b}}$ & $<0.01$ \\
\hline $2^{\text {nd }}$ passage & & & & & \\
\hline
\end{tabular}

a, b Means within the same row with different letters are significantly different $(\mathrm{P}<0.05)$ or $(\mathrm{P}<0.01)$ 


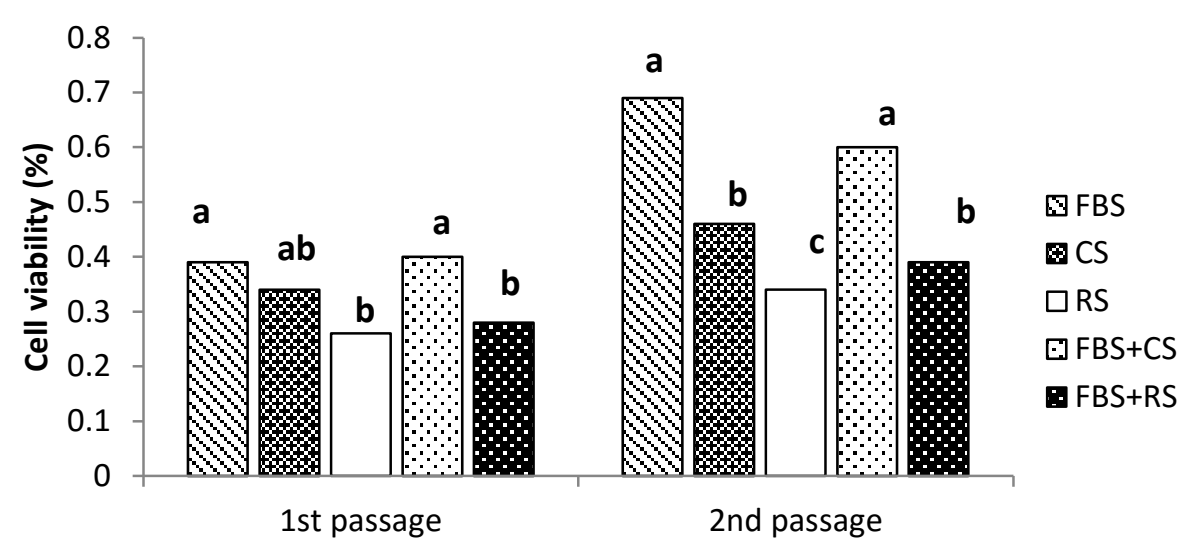

Figure (2): Effects of the different types of serum on the percentages of MDBK and VERO cell viability (\%) in first and second passage MTT assays (mean $\pm \mathrm{SE}$ ).

Various percentages of serum in MEM ranging from 2\% to $10 \%$ were tested to determine the best concentration. In the first passage $8 \%$ was the best concentration for FBS and CS, yielding viabilities of 0.51 and 0.48

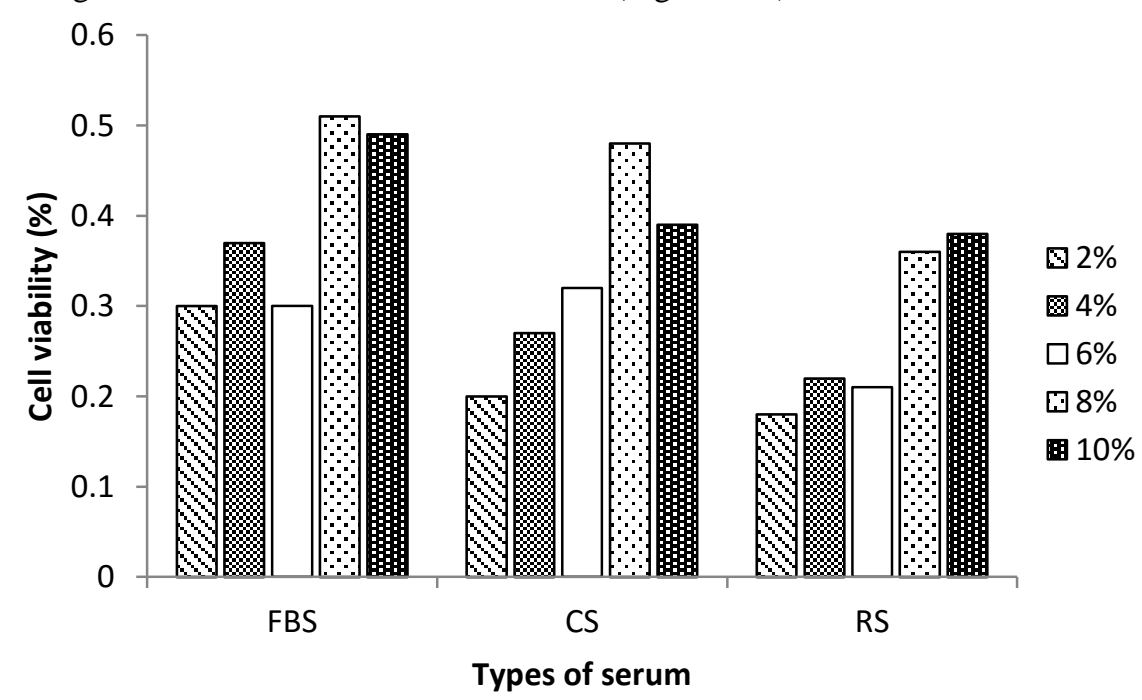

Types of serum respectively, however, $10 \%$ was the best concentration for mixed FBS and CS, RS and mixed FBS and RS, yielding viabilities of $0.5,0.38$ and 0.41 respectively (Figure3\&4) .

Figure (3): Effects of different concentrations of FBS, CS and RS on cell viability (\%) in first passage MTT assays $($ mean $\pm \mathrm{SE})$.

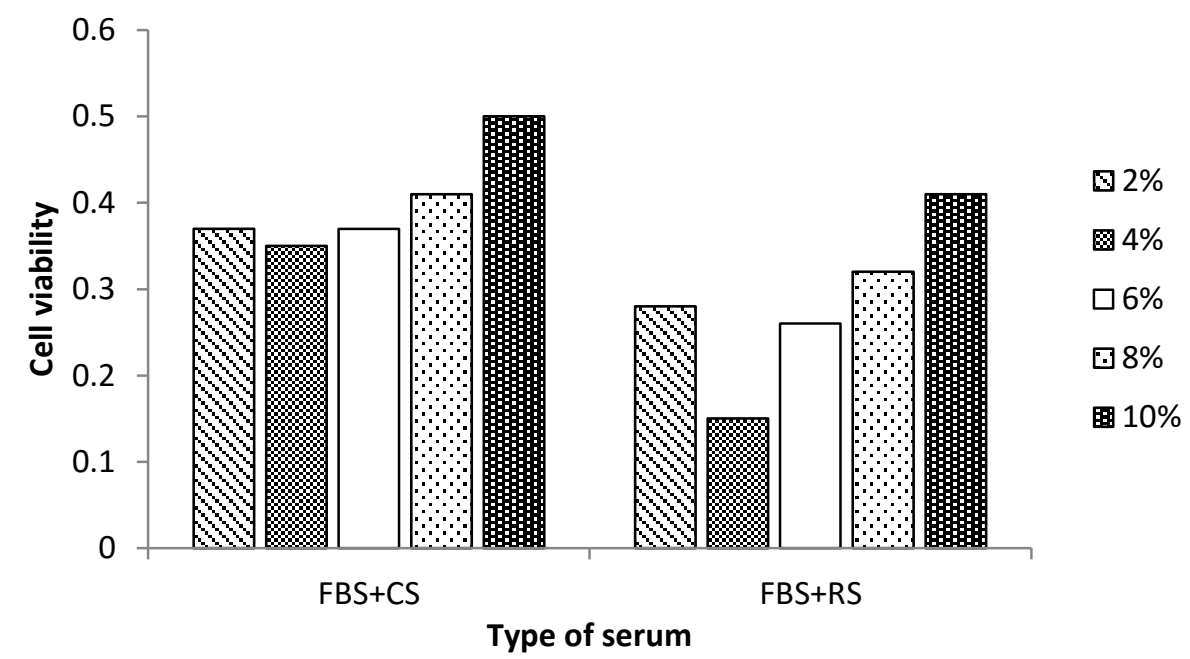

Figure (4): Effects of different concentrations of FBS+ CS and FBS+ RS on cell viability (\%) in first passage MTT assays (mean $\pm \mathrm{SE})$. 
In the second passage, the percentages of cell viability persisted despite decreased FBS, RS and mixed FBS and RS concentrations of, $6 \%, 8 \%$ and $4 \%$ respectively. The percentages remained constant in the CS and mixed FBS and CS groups, as shown in (Table 2) and (Figure 5 and $6)$.

Table 2: Effects of different concentrations of different types of serum on cell viability (\%) in MTT assays (mean \pm SE).

\begin{tabular}{ccccccc}
\hline \multirow{2}{*}{ Type of serum } & \multicolumn{7}{c}{ Cell viability at first passage (\%) } \\
\cline { 2 - 6 } & \multicolumn{7}{c}{ Serum concentration } & \multirow{2}{*}{ P value } \\
\cline { 2 - 7 } & $2 \%$ & $4 \%$ & $6 \%$ & $8 \%$ & $10 \%$ & $<0.01$ \\
\hline FBS & $0.30 \pm 0.01 \mathrm{c}$ & $0.37 \pm 0.07 \mathrm{~b}$ & $0.30 \pm .01 \mathrm{c}$ & $0.51 \pm 0.03 \mathrm{a}$ & $0.49 \pm 0.02 \mathrm{a}$ & $<0.01$ \\
\hline CS & $0.20 \pm 0.04 \mathrm{c}$ & $0.27 \pm 0.01 \mathrm{bc}$ & $0.32 \pm 0.01 \mathrm{~b}$ & $0.48 \pm 0.03 \mathrm{a}$ & $0.39 \pm 0.01 \mathrm{~b}$ & $<0.05$ \\
\hline RS & $0.18 \pm .007 \mathrm{~b}$ & $0.22 \pm 0.008 \mathrm{~b}$ & $0.21 \pm 0.004 \mathrm{~b}$ & $0.36 \pm 0.05 \mathrm{a}$ & $0.38 \pm 0.03 \mathrm{a}$ & $<0.05$ \\
\hline FBS+CS & $0.37 \pm 0.05 \mathrm{~b}$ & $0.35 \pm 0.01 \mathrm{~b}$ & $0.37 \pm .03 \mathrm{~b}$ & $0.41 \pm 0.08 \mathrm{~b}$ & $0.50 \pm 0.01 \mathrm{a}$ & $<0.01$ \\
\hline FBS+RS & $0.28 \pm 0.03 \mathrm{~b}$ & $0.15 \pm 0.03 \mathrm{c}$ & $0.26 \pm 0.01 \mathrm{~b}$ & $0.32 \pm 0.04 \mathrm{~b}$ & $0.41 \pm 0.03 \mathrm{a}$ & $<0.05$ \\
\hline FBS & $0.55 \pm 0.01 \mathrm{~b}$ & $0.68 \pm 0.08 \mathrm{ab}$ & $0.78 \pm 0.05 \mathrm{a}$ & $0.76 \pm 0.02 \mathrm{a}$ & $0.70 \pm 0.03 \mathrm{a}$ & $<0.01$ \\
\hline CS & $0.32 \pm 0.01 \mathrm{~b}$ & $0.45 \pm 0.07 \mathrm{ab}$ & $0.48 \pm 0.06 \mathrm{a}$ & $0.59 \pm 0.08 \mathrm{a}$ & $0.45 \pm 0.01 \mathrm{ab}$ & $<0.010 .0 .01 \mathrm{~b}$ \\
\hline RS & $0.25 \pm 0.01 \mathrm{c}$ & $0.34 \pm 0.02 \mathrm{~b}$ & $0.41 \pm 0.01 \mathrm{a}$ & $0.37 \pm 0.01 \mathrm{ab}$ & $0.35 \pm 0.01 \mathrm{~b}$ & $<0.01$ \\
\hline FBS+CS & $0.53 \pm 0.06 \mathrm{~b}$ & $0.59 \pm 0.01 \mathrm{~b}$ & $0.59 \pm 0.06 \mathrm{~b}$ & $0.54 \pm 0.08 \mathrm{~b}$ & $0.76 \pm 0.01 \mathrm{a}$ & $<0.05$ \\
\hline FBS+RS & $0.38 \pm 0.07$ & $0.40 \pm 0.08$ & $0.43 \pm 0.05$ & $0.35 \pm 0.05$ & $0.42 \pm 0.09$ & $\mathrm{NS}$
\end{tabular}

$\mathrm{a}, \mathrm{b}, \mathrm{c}$ Means within the same row with different letters are significantly different $(\mathrm{P}<0.05)$ or $(\mathrm{P}<0.01)$

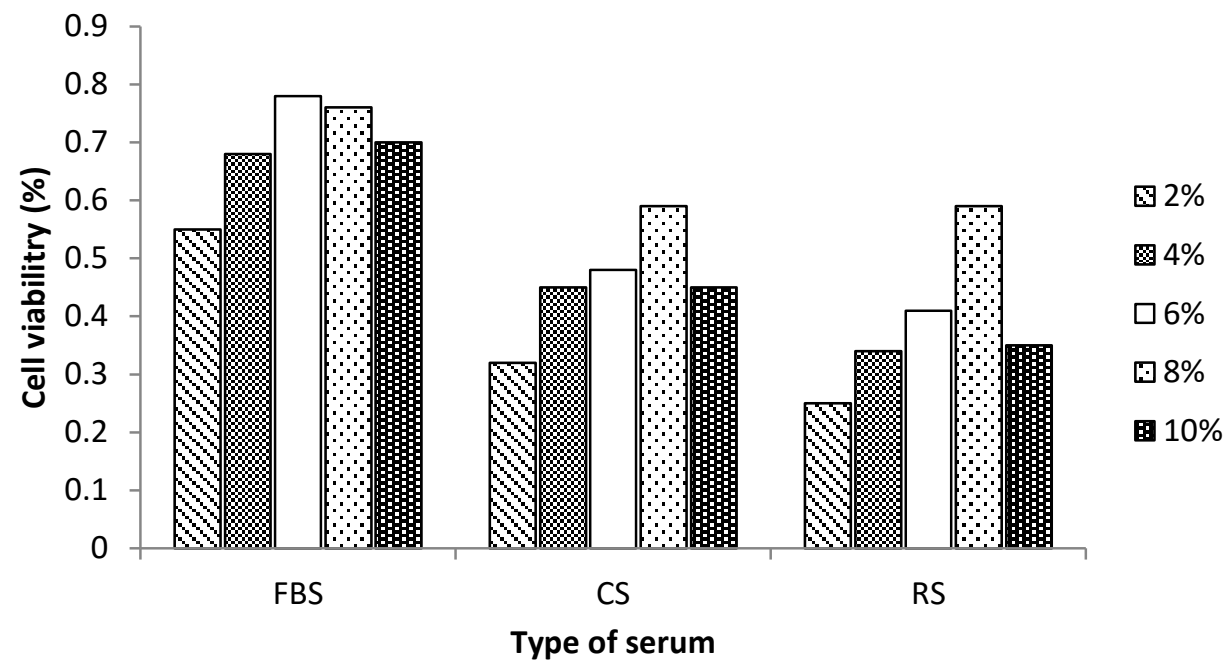

Figure (5): Effects of different concentrations of FBS, CS and RS on cell viability (\%) in second passage MTT assays $($ mean $\pm \mathrm{SE})$.

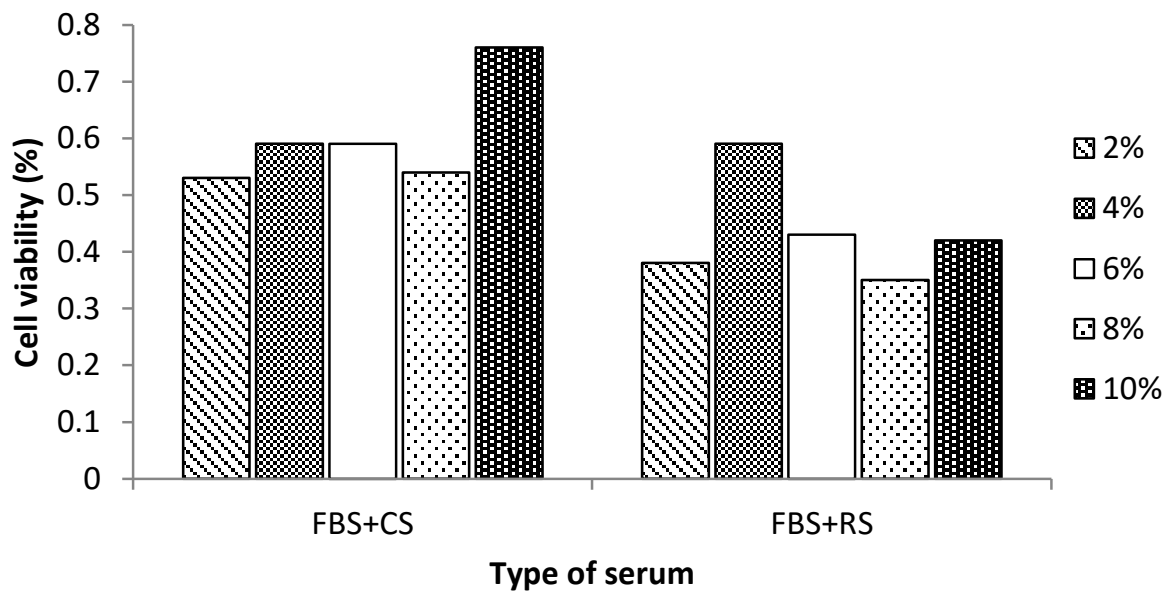

Figure (6): Effects of different concentrations of FBS+ CS and FBS+ RS on cell viability (\%) in second passage MTT assays (mean $\pm \mathrm{SE})$. 
The comet assays gave the same results as MTT assays FBS-treated MDBK and VERO cells exhibited lower percentages of DNA damage than both CS and RStreated cells. The comet percentages for FBS, CS and RS were $7 \%, 19.6 \%$ and $24 \%$ respectively, in the first passage and $6 \%, 13 \%$ and $16.2 \%$, respectively, in the second passage as shown in (Table 3 ).

Table 3: Comet assays were performed on MDBK cells supplemented with FBS, CS and RS to determine degree of DNA damaged in the head and tail.

\begin{tabular}{cccccccc}
\hline \multirow{2}{*}{$\begin{array}{c}\text { Type of } \\
\text { serum }\end{array}$} & $\begin{array}{c}\text { Comet } \\
(\%)\end{array}$ & $\begin{array}{c}\text { Head } \\
\text { diameter }(\mathbf{P x})\end{array}$ & $\begin{array}{c}\text { Head DNA } \\
(\boldsymbol{\%})\end{array}$ & $\begin{array}{c}\text { Tail length } \\
(\mathbf{P x})\end{array}$ & $\begin{array}{c}\text { Tail DNA } \\
(\boldsymbol{\%})\end{array}$ & $\begin{array}{c}\text { Tail } \\
\text { moment }\end{array}$ & $\begin{array}{c}\text { Olive tail } \\
\text { moment }\end{array}$ \\
\hline FBS & $7 \%$ & $43.51 \pm 0.25^{\mathrm{a}}$ & $95.41 \pm 0.20^{\mathrm{a}}$ & $8.02 \pm 0.01^{\mathrm{a}}$ & $4.28 \pm 0.04^{\mathrm{b}}$ & $0.34 \pm 0.05^{\mathrm{b}}$ & $0.71 \pm 0.05^{\mathrm{b}}$ \\
\hline CS & $19.6 \%$ & $32.42 \pm 0.01^{\mathrm{c}}$ & $92.52 \pm 0.01^{\mathrm{b}}$ & $5.57 \pm 0.03^{\mathrm{b}}$ & $7.4 \pm 0.08^{\mathrm{a}}$ & $0.33 \pm 0.05^{\mathrm{b}}$ & $0.92 \pm 0.05^{\mathrm{a}}$ \\
\hline RS & $24 \%$ & $39.70 \pm 0.01^{\mathrm{b}}$ & $95.54 \pm 0.02^{\mathrm{a}}$ & $8.13 \pm 0.03^{\mathrm{a}}$ & $4.40 \pm 0.05^{\mathrm{b}}$ & $0.40 \pm 0.05^{\mathrm{a}}$ & $0.72 \pm 0.02^{\mathrm{b}}$ \\
\hline \multicolumn{7}{c}{ Second passage $^{\mathrm{yyyyy}}$} \\
\hline FBS & $6 \%$ & $36.14 \pm 0.008^{\mathrm{a}}$ & $91.36 \pm 0.08^{\mathrm{b}}$ & $4.04 \pm 0.02^{\mathrm{b}}$ & $8.61 \pm 0.08^{\mathrm{a}}$ & $0.27 \pm 0.003^{\mathrm{c}}$ & $1.14 \pm 0.008^{\mathrm{a}}$ \\
\hline CS & $13 \%$ & $37.56 \pm 0.005^{\mathrm{a}}$ & $94.67 \pm 0.11^{\mathrm{a}}$ & $7.31 \pm 0.05^{\mathrm{ab}}$ & $5.41 \pm 0.51^{\mathrm{b}}$ & $0.39 \pm 0.005^{\mathrm{b}}$ & $0.77 \pm 0.008^{\mathrm{b}}$ \\
\hline RS & $16.2 \%$ & $38.27 \pm 0.005^{\mathrm{a}}$ & $95.35 \pm 0.05^{\mathrm{a}}$ & $8.51 \pm 0.05^{\mathrm{a}}$ & $4.95 \pm 0.65^{\mathrm{b}}$ & $0.44 \pm 0.005^{\mathrm{a}}$ & $0.75 \pm 0.005^{\mathrm{b}}$ \\
\hline
\end{tabular}

$\mathrm{a}, \mathrm{b}, \mathrm{c}$ Means within the same column with different letters are significantly different $(\mathrm{P}<0.05)$ or $\mathrm{P}<0.01)$

FBS: foetal bovine serum, CS: camel serum, RS: rabbit serum.

In a horizontal electrophoresis apparatus, undamaged DNA is supercoiled and thus does not migrate very far from the nucleoid under the influence of an electric current; such undamaged DNA was observed in MDBK cells supplemented with FBS and at high levels in MDBK cells supplemented with CS. In cells that have accrued DNA damage, the alkali treatment
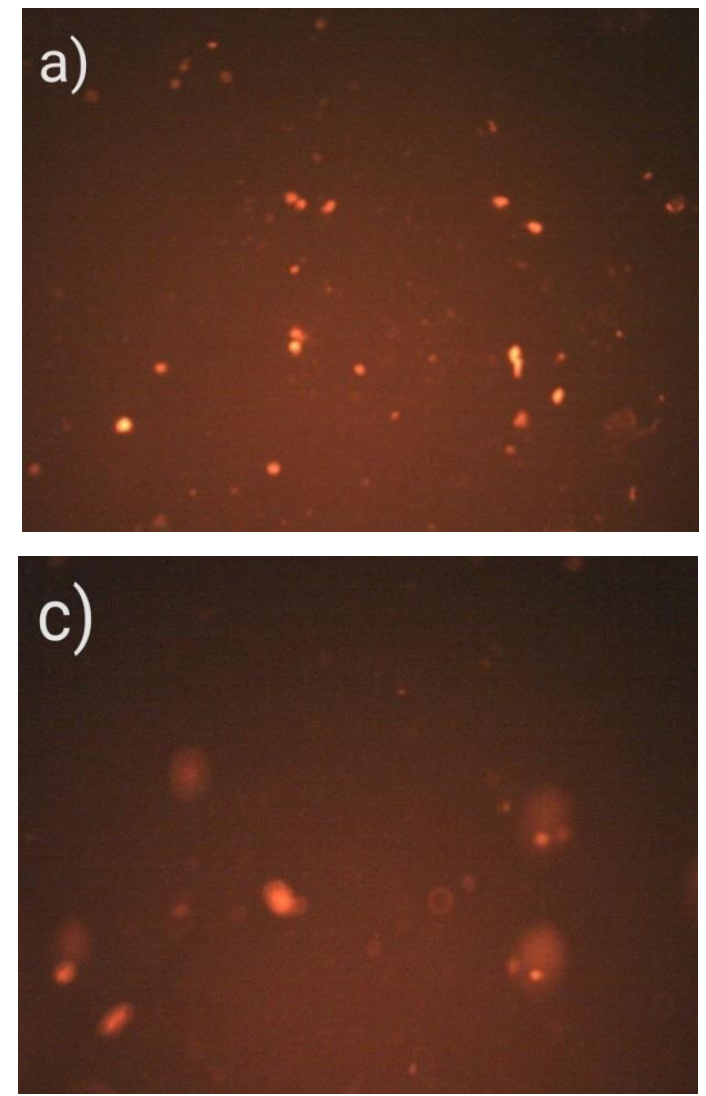

unwinds the DNA, releasing fragments that migrate from the cell when subjected to an electric field. The negatively charged DNA migrates towards the anode, and the extrusion length reflects the relaxation of supercoil, which is indicative of damage; such damage was observed in cells cultured with RS (Figure 7).
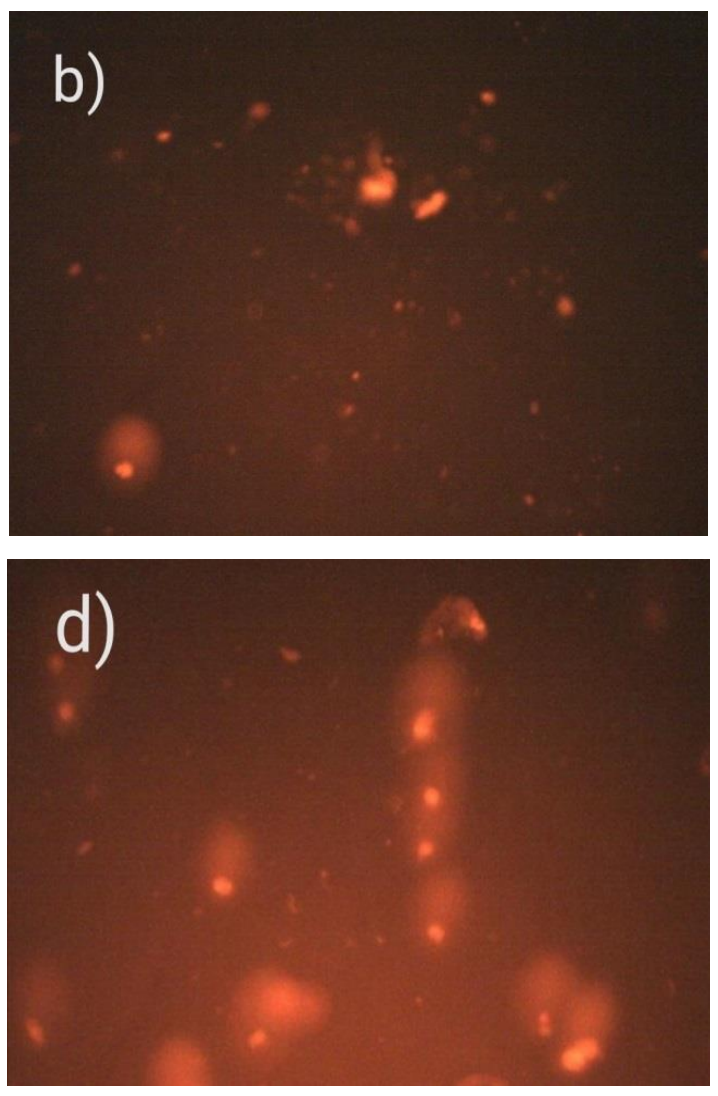

Figure (7): Representative microscopic images of the comet assay results for a) intact, normal MDBK cells, b) FBS supplemented MDBK cells with low DNA damage c) CS -supplemented MDBK cells with moderate DNA damage and d) RS-supplemented MDBK cells with high levels of DNA damage. 


\section{DISCUSSION}

The different types of serum are used for cell culture growth. The most commonly source is FBS (Barnes and sato, 1980). FBS is commonly harvested by means of a cardiac puncture without any form of anesthesia. Fetuses are likely exposed to pain and/or discomfort and therefore current practice of foetal blood harvest is inhumane and a lot of fetuses are gone (Carlo et al., 2002). Therefore the researchers seek for another available and cheap source such as goat serum, horse serum, camel serum or human serum (smita 2004, Rauch et al., 2011 and Charlotte et al., 2018). In this study, CS and RS compared with FBS. The convergent results between FBS and CS can be attributed to the charge/mass ratio and surface hydrophobicity of the CS was similar to that of FBS (Ajamaluddin et al., 2013). By using of different serum dilution, we see that the viability of cells increases by increasing the percentage of serum (Aasif et al., 2015).

From the above outcomes, we can confirm that CS more beneficial than RS. Additionally, we suggest using CS, a less expensive and more accessible serum than FBS, either alone or mixed with FBS.

\section{ACKNOWLEDGEMENTS}

The authors thank Prof Dr. Mohammed Saad (Animal Reproductive Research Institute, ARRI) for his collaboration and assistance. The authors also thank Prof. Dr. Abeer M. Anwer (Immunobiology and Pharmacology Unit, ARRI) for her help and collaboration. Thanks a lot for SPRINGER NATURE for editing our paper.

\section{REFERENCES}

Aasif Durrani, Arshiya Mirza, Zia H Khan, Naziya Khan, Surekha S. Kulkarni and Yusuf A. Ali (2015): Adaptation of mammalian cell from $10 \%$ serum medium to serum free or low serum media. International journal of applied research 2015; 1(9): 770-75.

Ajamaluddin Malik, Abdulrahman Al-Senaidy, Ewa Skrzypczak-Jankun and Jerzy Jankun (2013): Isolation and characterization of serum albumin from camelus dromedaries. Experimental and therapeutic medicine 2013; 6: 519-524.

Barnes, D. and Sato, G. (1980): Serum-free cell culture: a unifying approach.Cell.1980; 22: 649-55.

Carlo, EA. Jochems, Jan BF van der Valk, Frans $R$ Stafleu and Vera Baumans (2002): the use of fetal bovine serum: ethical or scientific problem?. ATLA 30,219-227.

Charlotte Saury, Aurélie Lardenois, Cindy Schleder, Isabelle Leroux, Blandine Lieubeau, Laurent David, Marine Charrier, Laëtitia Guéve, Sabrina Viau, Bruno Delorme and Karl Rouger (2018): Human serum and platelet lysate are appropriate xeno-free alternatives for clinical-grade production of human MuStem cell batches. Saury et al. Stem Cell Research \& Therapy (2018) 9: 128.

Doumas, BT.; Watson, WA. and Biggs, HG. (1971): albumin standars and the measurement of serum albumin with bromocresol green. Clin. Chim. Acta, 31: 87-96.

Doumas, BT.; Bayse, DD.; Carter, RJ.; Peters, TJR. and Schaffer, R. (1981): candidate reference method for determination of total protein in serum. I. Development and validation. II. Tests for transferability. Clin. Chem. 27: 1642-1654.

Eagle, H. (1955): Nutrition needs of mammalian cells in tissue culture. Science 122, 3168, 501-514.

Edward, S. (1990): The diagnosis of bovine virus diarrhea mucosal disease in cattle. Revue scientifique et technique. OIE, 9: 115-130.

Fransiska Zakaria-Runkat, Wanchai Worawattanamateekul and Ong-ard Lawhavinit (2006): Production of Fish Serum Products as Substitute for Fetal Bovine Serum in Hybridoma Cell Cultures from Surimi Industrial Waste. Kasetsart J. (Nat. Sci.) 40 (Suppl.) : 198 - 205.

Freundt, E.A. (1983): culture media for classic mycoplasma in "mrthods in mycoplasmology" Vol. 1 Razin, S. and Tully, J. G. eds., academic press, Newyork, pp. 127-146.

Geetha, B. (2017): Fluorescent Antibody Staining Procedure for Detection of Viral Antigens United of Agriculture States Department Center for Veterinary Biologics Testing Protocol NO. VIRPRO1014.06 https://www.aphis.usda.gov/ animal_health/vet_biologics/publications/VIRPR O1014.pdf.

Jin, X.; Xu, Q.; Champion, K. and Kruth, HS. (2015): Endotoxin contamination of apolipoprotein A-I: effect on macrophage proliferation - a cautionary tale. Atherosclerosis. 2015; 240: 121-4.

Johan van Meerloo, Gertjan J.L. Kaspers, and Jacqueline Cloos (2011): Cell Sensitivity Assays: The MTT Assay. Methods and Protocols, Second Edition, Methods in Molecular Biology, vol. 731, DOI 10.1007/978-1-61779-080-5_20. publication at: https://www.researchgate.net/publication/ $\underline{51073437 .}$.

John E. Piletz, Jennifer Drivon, John Eisenga, Will Buck, Sabrina Yen, Megan McLin, William Meruvia, Carolina Amaral and Kellie Brue (2018): Human Cells Grown With or Without Substitutes for Fetal Bovine Serum. First Published June 6, 2018. Research Article https://doi.org/ 10.1177/2155179018755140

Karnieli, O.; Friedner, OM.; Allickson, JG.; Zhang, N.; Jung, S.; Fiorentini, D.; Abraham, E.; Eaker, SS.; Yong, TK.; Chan, A.; Griffiths, S. and When, AK. (2017): A consensus introduction to serum replacements and serum-free media for cellular therapies. Cytotherapy. 2017; 19: 155-69.

Mesalam, A.; Lee, KL.; Khan, I.; Chowdhury, MMR.; Zhang, S.; Song, SH.; Joo, MD.; Lee, JH.; Jin, JI. 
and Kong, IK. (2019): A combination of bovine serum albumin with insulin transferrin-sodium selenite and/or epidermal growth factor as alternatives to fetal bovine serum in culture medium improves bovine embryo quality and trophoblast invasion by induction of matrix metalloproteinases.Reprod Fertil Dev.2019 Jan; 31(2): 333-346.

Microbeonline (2014): Common Fungal Culture Media and their uses. updated on August 3rd, 2019. https://microbeonline.com/common-fungalculture-media-use/.

Nanda P.K.; Swain, P.; Nayak, S.K.; Dash, S.; Routray, P.; Swain, S.K. and Patra, B.C. (2009): Goat serum as an alternative to establish cell culture from Indian major crap, Cirrhinus mrigala. In vitro cell. Dev.Biol-Animal; 45:148-151.

Oxoid Manual (1996): the oxoid manual of culture media ingredients and Basingstoke, Hampshire, England.

Rauch, C.; Feifel, E.; Amann, EM.; Spötl, HP.; Schennach, H.; Pfaller, W. and Gstraunthaler, G. (2011): Alternatives to the Use of Fetal Bovine Serum: Human Platelet Lysates as a Serum Substitute in Cell Culture Media. ALTEX. 2011; 28(4): 305-16.

Singh, N.P.; McCoy, M.T.; Tice, R.R. and Schneider, E.L. (1988): A simple technique for quantitative of low levels of DNA damage in individual cells. Exp. Cell Res., 175 (1988), PP. 184-191.
Smita Paranjape (2004): Goat serum: An alternative to fetal bovine serum in biomedical research. Indian journal of Experimental Biology. Vol.42, Jaunary 2004, pp.26-35.

Spees, JL.; Gregory, CA.; Singh, H.; Tucker, HA.; Peister, A.; Lynch, PJ.; Hsu, SC.; Smith, J. and Prockop, DJ. (2004): Internalized antigens must be removed to prepare hypoimmunogenic mesenchymal stem cells for cell and gene therapy. Mol Ther J Am Soc Gene Ther. 2004; 9: 747-56.

Tekkatte, C.; Gunasingh, GP.; Cherian, KM. and Sankaranarayanan, K. (2011): "Humanized"stem cell culture techniques: the animal serum controversy. Stem Cells Int. 2011; Volume 2011: Article ID 504723, 14 pages. doi: 10.4061/ 2011/504723.

Van Der Valk, J.; Mellor, D.; Brands, R.; Fischer, R.; Gruber, F.; Gstraunthaler, G.; Hellebrekers, L.; Hyllner, J.; Jonker, F.H.; Prieto, P.; Thalen, M. and Baumans, V. (2004): The humane collection of fetal bovine serum and possibilities for serumfree cell and tissue culture. Toxicology In Vitro $18,1,1-12$.

Van Der Valk, J.; Brunner, D.; De Smet, K.; Fex Svenningsen, A.; Honegger, P.; Knudsen, LE.; Lindl, T.; Noraberg, J.; Price, A.; Scarino, ML. and Gstraunthaler, G. (2010): Optimization of chemically defined cell culture media--replacing fetal bovine serum in mammalian in vitro methods. Toxicol In Vitro. Jun; 24(4): 1053-63.

\section{مقارنة بين آثار مصل الابقاروتأثيرات مصل الإبل والأرانب على بعض أنواع زراعة الأنسجة

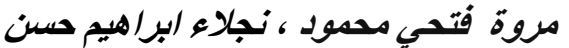

E-mail: asiamarwa1911@gmail.com Assiut University web-site: www.aun.edu.eg

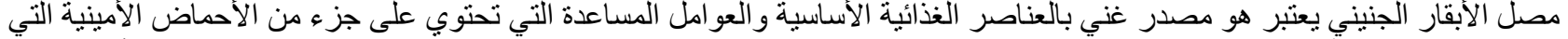

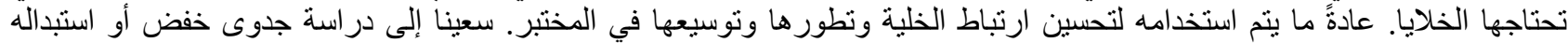

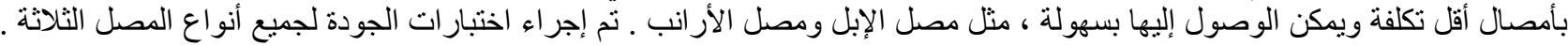

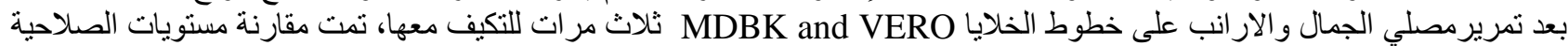

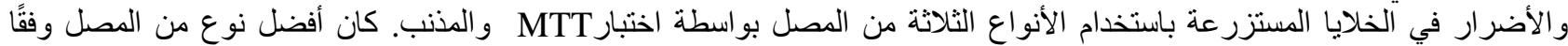

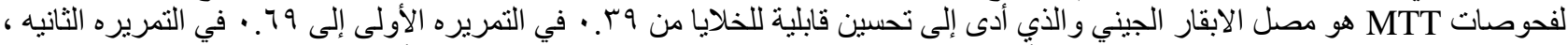

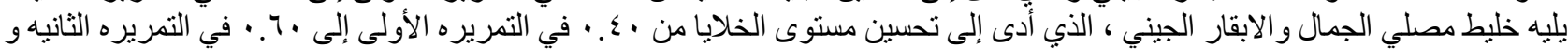

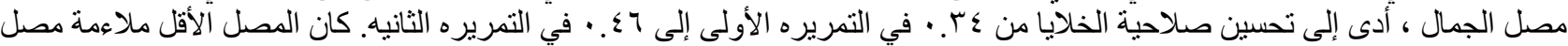

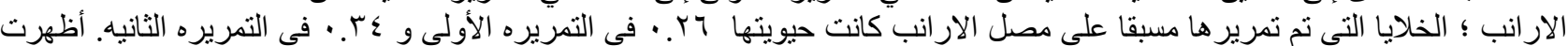

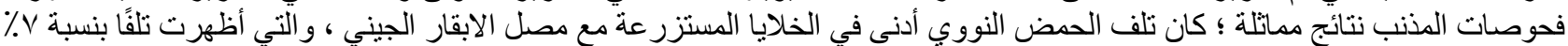

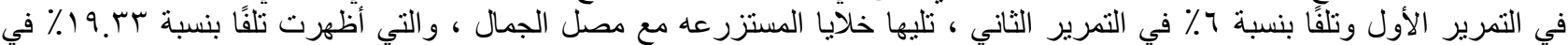

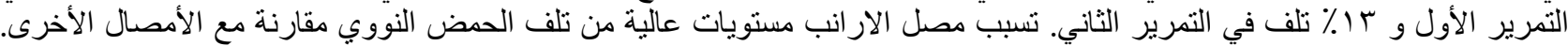

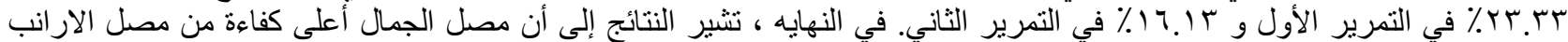
ويمكن استخدامه كبديل عن مصل الابقار الجيني أو في خليط متساوِي مع مصل التيل الابقار الجيني لتعزيز نمو الخلايا.
} 